\title{
Purification and characterization of xanthine oxidase from liver of the water buffalo Bubalus bubalis
}

\author{
Mahmoud A. Ibrahim ${ }^{1}$, Hassan M.M. Masoud ${ }^{1 *}$, Doaa A. Darwish ${ }^{1}$, Sayed S. Esa ${ }^{1}$, Samir A.M. Zaahkouk ${ }^{2}$ \\ ${ }^{1}$ Molecular Biology Department, National Research Centre, El-Tahrir st., Dokki, Giza, Egypt. \\ ${ }^{2}$ Zoology Department, Faculty of Science, Al-Azhar University, Cairo, Egypt.
}

\begin{tabular}{l} 
ARTICLE INFO \\
\hline Article history: \\
Received on: $11 / 08 / 2015$ \\
Revised on: $26 / 08 / 2015$ \\
Accepted on: 03/10/2015 \\
Available online: $27 / 11 / 2015$ \\
\hline Key words: \\
Xanthine oxidase; \\
Purification; \\
Characterization; Buffalo \\
liver, Medical applications
\end{tabular}

\begin{abstract}
Xanthine oxidase (XO) is an important enzyme with broad medical applications as detecting reagent in many diagnostic kits. In this study, buffalo liver xanthine oxidase (BLXO) was purified to homogeneity by acetone precipitation and chromatography on DEAE-cellulose and Sephacryl S-300 columns with a specific activity of 7.2 units / mg protein which represent 31.3 folds. The native molecular weight of the purified enzyme is $200 \mathrm{kDa}$ and its subunit molecular weight was determined by SDS-PAGE to be $67 \mathrm{kDa}$. The isoelectric point $(p \mathrm{I})$ value of BLXO isoenzyme is at $\mathrm{pH} 6.0-6.2$. It displayed its $\mathrm{pH}$ optima at 7.6 and the $\mathrm{Km}$ value is $1.1 \mathrm{mM}$ xanthine. $\mathrm{FeCl}_{2}$ increased the activity of BLXO while $\mathrm{CuCl}_{2}, \mathrm{MnCl}_{2}$ and $\mathrm{ZnCl}_{2}$ were found to be inhibitors of the purified enzyme. Allopurinol inhibits BLXO competitively and has one binding site on it with Ki value of $0.025 \mathrm{mM}$.
\end{abstract}

Abbreviations: BSA, Bovine serum albumin, XO, Xanthine oxidase, NBT, Nitroblue tetrazolium, PAGE, Polyacrylamide gel electrophoresis, PMS, Phenazine methosulphate, BLXO, Buffalo liver xanthine oxidase

\section{INTRODUCTION}

Xanthine oxidase (XO) (EC 1.2.3.22) catalyzes the oxidation of xanthine and hypoxanthine into uric acid (Nguyen et al., 2005). XO has a quaternary structure in which each subunit contains molybdopterin, flavin adenine dinucleotide and ironsulfur center (Kuwabara et al., 2003). This enzyme is widely used as a detector for nucleotidases, purines, superoxide dismutases, adenosine deaminase, phosphates of blood serum and in the determination of liver diseases (Heinz et al., 1980; Groot and Noll, 1985). It had also been reported as playing vital roles in innate immune system (Vorbach et al., 2003), diseases of cardiovascular system (Berry and Hare, 2004) and employed as antimicrobial agent (Martin et al., 2004, Zhang et al., 2012). XO plays important roles in hyperuricemia and gout since XO inhibitors; allopurinol, oxypurinol and febuxostat have been used widely for the treatment of such disorders. The inhibition of XO reduces the vascular oxidative stress and circulating levels of uric

\footnotetext{
* Corresponding Author

Hassan Mohamed Masoud, Molecular Biology Department, National Research Centre, El-Tahrir st., Dokki, Giza, Egypt.

Email: hssnmasoud @ yahoo.com
}

acid. In addition, the superoxide anion radicals generated by $\mathrm{XO}$ are involved in various pathological processes such as liver diseases, inflammatory diseases, aging, and carcinogenesis. Thus, XO inhibitors may be useful for treatment of many other diseases (Nguyen et al., 2005; Higgins et al., 2011). Xanthine oxidase has been purified from several sources including human liver (Krenitsky et al., 1986; Moriwaki et al., 1993), rabbit liver (Catignani et al., 1975), mouse liver (Carpani et al., 1990; McManaman et al., 1996; Maia and Mira, 2002), rat skeletal muscle (Lalanne and Willemot, 1975), human milk (Abadeh et al., 1992), cow milk (Waud et al., 1975; Nishino et al., 1981; Spitsberg and Gorewit, 1998; Ozer et al., 1999; Belattar, 2009), Arthrobacter sp bacteria (Xin et al., 2012; Zhang et al., 2012). In this study, we purify and characterize XO from the buffalo liver for using it in preparation of superoxide dismutase diagnostic kit which has wide use in medical applications.

\section{MATERIALS AND METHODS}

\section{Liver material}

Six fresh buffalo liver samples were obtained from different individuals in a local slaughter-house and stored at $-40{ }^{\circ} \mathrm{C}$. 


\section{Chemicals}

Xanthine sodium salt, Nitroblue tetrazolium (NBT), Phenazine methosulphate (PMS), Albumin from bovine serum (BSA), Diethylaminoethyl-cellulose (DEAE-Cellulose), Sephacryl S-300 and chemicals for electrophoresis were purchased from Sigma-Aldrich Chemical Co. The other chemicals were of analytical grade.

\section{Assay of xanthine oxidase activity}

The XO activity assay reaction contained in $1 \mathrm{ml}$ of 0.05 M Tris- $\mathrm{HCl}, \mathrm{pH} 7.6$ containing $2 \mathrm{mM}$ xanthine, $0.5 \mathrm{mM} \mathrm{NBT}$ and the xanthine oxidase solution. The reaction mixture was incubated for 5 minutes at $37{ }^{\circ} \mathrm{C}$, centrifuged and the absorbance was measured at $575 \mathrm{~nm}$. To calculate XO units, a control reaction was done with 0.02 unit commercially available bovine milk xanthine oxidase (Agarwal and Banerjee, 2009).

\section{Xanthine oxidase activity staining on polyacrylamide gels}

Activity staining of xanthine oxidase was determined as described by (Ozer et al., 1998). The gels were submerged in 50 $\mathrm{mM}$ Tris $/ \mathrm{HCl}, \mathrm{pH} 7.6,0.5 \mathrm{mM}$ xanthine, $0.25 \mathrm{mM}$ nitroblue tetrazolium and $630 \mathrm{mM}$ TEMED. Staining of the gels was continued till the activity bands appear on the gels.

\section{Purification of xanthine oxidase from buffalo liver Preparation of crude extract}

All of the procedures were performed at $4^{\circ} \mathrm{C} .100 \mathrm{gm}$ of liver were minced and homogenized with $0.02 \mathrm{M}$ Tris/HCI buffer, $\mathrm{pH} 7.6$, containing $0.1 \mathrm{mM}$ EDTA on ice and mixed with one volume of n-butanol. The mixture was kept at $-20^{\circ} \mathrm{C}$ overnight and centrifuged at $12000 \times \mathrm{g}$ for $30 \mathrm{~min}$ at $4^{\circ} \mathrm{C}$. The aqueous phase containing the enzyme activity was saved and designated nbutanol fraction. One volume prechilled acetone was added to the n-butanol fraction. The pellet was collected after centrifugation at $12000 \times \mathrm{g}$ for $30 \mathrm{~min}$ at $4^{\circ} \mathrm{C}$, washed three times with acetone and dried under vacuum. The acetone powder was dissolved in $0.02 \mathrm{M}$ Tris/HCI buffer, $\mathrm{pH} 7.6$, containing $0.1 \mathrm{mM}$ EDTA and designated acetone fraction (Oida et al., 1984).

\section{DEAE-cellulose column Chromatography}

The acetone fraction was applied on DEAE-cellulose column (6 x $2.4 \mathrm{~cm}$ i.d.) equilibrated with $0.02 \mathrm{M}$ Tris/HCI buffer, $\mathrm{pH} 7.6$, containing $0.1 \mathrm{mM}$ EDTA. The protein fractions were eluted with stepwise $\mathrm{NaCl}$ gradient ranging from 0 to $1 \mathrm{M}$ prepared in the equilibration buffer at a flow rate of $60 \mathrm{ml} / \mathrm{hr} .5$ $\mathrm{ml}$ fractions were collected and the fractions containing $\mathrm{XO}$ activity were pooled and concentrated by lyophilization.

\section{Sephacryl S-300 column Chromatography}

The concentrated material containing XO activity was applied to a Sephacryl S-300 column (142 cm X $1.75 \mathrm{~cm}$ i.d.). The column was equilibrated and run with $0.02 \mathrm{M}$ Tris/HCI buffer, $\mathrm{pH}$ 7.6, containing $0.1 \mathrm{mM}$ EDTA at a flow rate of $30 \mathrm{ml} / \mathrm{h}$ and $2 \mathrm{ml}$ fractions were collected.

\section{Electrophoretic analysis}

Native gel electrophoresis was carried out with $7 \%$ PAGE (Smith, 1969). SDS-PAGE was performed with $12 \%$ polyacrylamide gel (Laemmli, 1970). The subunit molecular weight of the purified XO enzyme was determined by SDS-PAGE (Weber and Osborn, 1969). Electrofocusing was performed and the isoelectric point $(\mathrm{pI})$ value was calculated from a calibration curve (O'Farrell, 1975; Ubuka et al. 1987). Coomassie brilliant blue R-250 was used to stain the proteins.

\section{Protein determination}

Protein content was determined by the dye binding assay method (Bradford, 1976) using BSA as a standard protein.

\section{RESULTS}

\section{Purification of XO enzyme from buffalo liver}

The XO specific activity of the buffalo liver was found to be 0.23 units $/ \mathrm{mg}$ protein. A typical purification scheme of XO from the buffalo liver is presented in table (1). The DEAEcellulose elution profile (Fig. 1a) revealed the presence of one peak containing XO activity designated BLXO and eluted with $0.05 \mathrm{M} \mathrm{NaCl}$. The DEAE-cellulose fractions of this peak were pooled, concentrated by lyophilization and applied onto a Sephacryl S-300 column. Sephacryl S-300 column (Fig. 1b) revealed the presence of one peak of BLXO enzyme activity. The BLXO was purified with a specific activity of 7.2 units / mg protein and 31.3 folds purification over the crude extract with $33.8 \%$ yield (Table 1 ).

Table 1: A typical purification scheme of the buffalo liver xanthine oxidase BLXO:

\begin{tabular}{|c|c|c|c|c|c|}
\hline Purification steps & 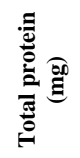 & 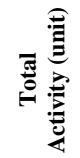 & 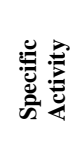 & 를 & 등 \\
\hline Acetone fraction & 84.4 & 19.5 & 0.23 & 100 & 1.0 \\
\hline DEAE-Cellulose fraction & 10.4 & 11.8 & 1.13 & 60.5 & 4.9 \\
\hline Sephacryl S-300 fraction & 0.92 & 6.6 & 7.2 & 33.8 & 31.3 \\
\hline
\end{tabular}

\section{Molecular weight determination by gel filtration}

The native molecular weight of BLXO eluted from Sephacryl S-300 column was deduced from a calibration curve to be $200 \mathrm{kDa}$.

\section{Electrophoretic analyses of BLXO}

Samples from crude extract, DEAE-cellulose and Sephacryl S-300 fractions of BLXO were analyzed electrophoretically on $7 \%$ native PAGE (Fig. 2a). Single protein band coincided with the enzyme activity band of the purified xanthine oxidase indicating the tentative purity of the preparation. SDS-PAGE of denatured purified BLXO enzyme calculated the subunit molecular weight to be $67 \mathrm{kDa}$ (Fig. 2b). The pI value of BLXO was calculated from a calibration curve to be at $\mathrm{pH}$ 6.0-6.2 (Fig. 2c). 

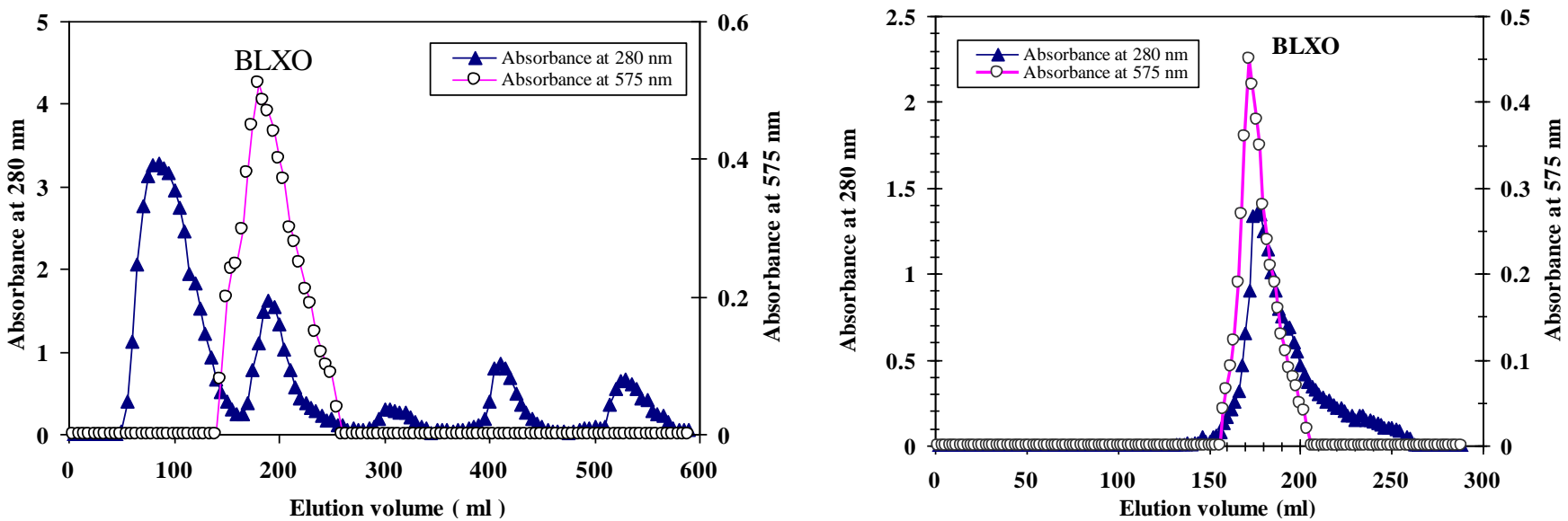

Fig. 1: (a) A typical elution profile for the chromatography of the buffalo liver on DEAE-cellulose column $(6 \mathrm{~cm} \times 2.4 \mathrm{~cm}$ i.d.) previously equilibrated with 0.02 $\mathrm{M}$ Tris-HCI buffer, $\mathrm{pH} 7.6$ containing $0.1 \mathrm{mM}$ EDTA. The proteins were eluted by a stepwise gradient of $\mathrm{NaCl}$ ranging from 0 to $1 \mathrm{M}$ in the equilibration buffer and $5 \mathrm{ml}$ fractions were collected at a flow rate of $60 \mathrm{ml} / \mathrm{h}$. (b) A typical elution profile for the chromatography of BLXO on Sephacryl S-300 column (142 cm x $2.4 \mathrm{~cm}$ i.d.) previously equilibrated with $0.02 \mathrm{M}$ Tris-HCI buffer, $\mathrm{pH} 7.6$ containing $0.1 \mathrm{mM}$ EDTA. The proteins were eluted by the same buffer and $2 \mathrm{ml}$ fractions were collected at a flow rate of $30 \mathrm{ml} / \mathrm{h}$.
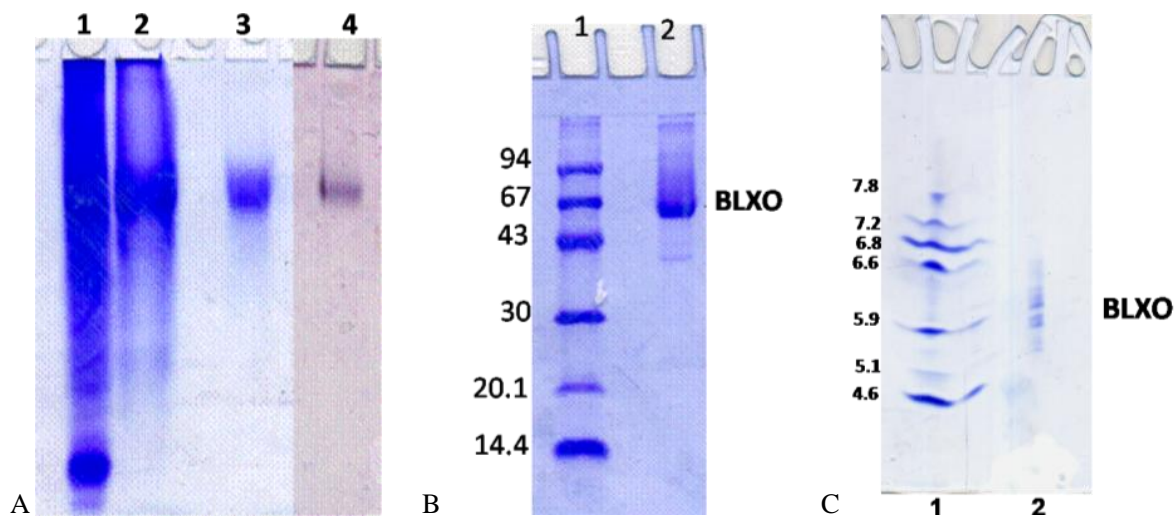

Fig. 2: (a) Electrophoretic analysis of protein pattern of BLXO on $7 \%$ native PAGE: (1) crude extract, (2) DEAE-cellulose fraction, (3) Sephacryl S-300 purified fraction and (4) Isoenzyme pattern of purified BLXO. (b) Molecular weight determination of BLXO subunit by 12\% SDS-PAGE: (1) Low molecular weight marker proteins and (2) Purified BLXO. (c) Isoelectrofocusing: (1) Isoelectric point ( $p I$ ) marker proteins, (2) The purified BLXO.
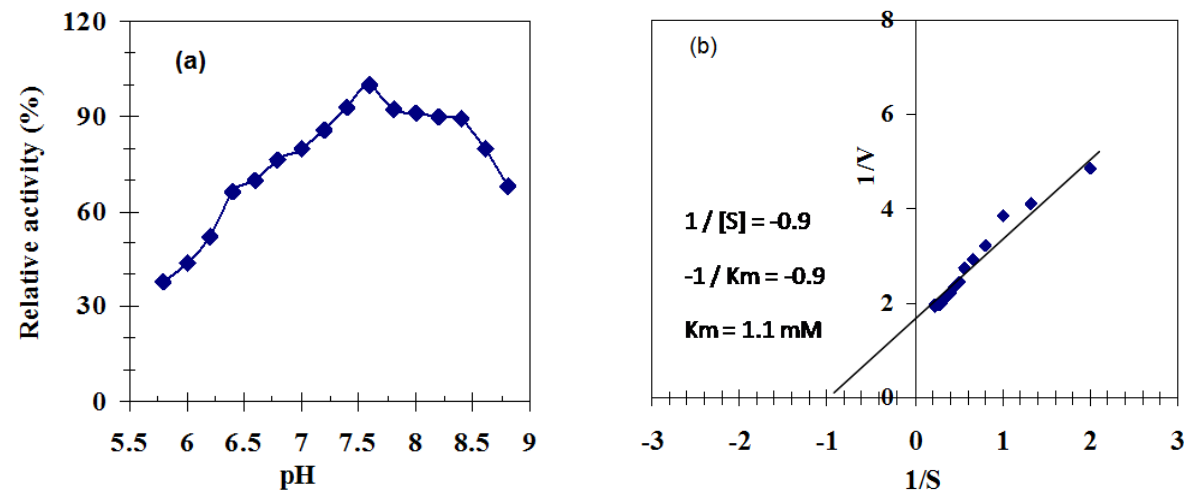

Fig. 3: (a) Effect of $\mathrm{pH}$ on the purified BLXO using $0.05 \mathrm{M}$ potassium phosphate buffer, $\mathrm{pH}$ (5.8-8.0) and 0.05 $\mathrm{M}$ Tris- $\mathrm{HCl}$ buffer, $\mathrm{pH}$ (8.0-9.0). (b) Lineweaver-Burk plot relating the reciprocal of the reaction velocity of the purified BLXO to xanthine concentration in $\mathrm{mM}$.

\section{Determination of BLXO optimum $\mathrm{pH}$ and $\mathrm{Km}$ value}

The effect of $\mathrm{pH}$ on the activity of BLXO was set in potassium phosphate and Tris-HCl buffers. The $\mathrm{pH}$ profile of BLXO displayed its optimum activity at $\mathrm{pH} 7.6$ (Fig. $3 \mathrm{a})$. The $\mathrm{Km}$ value was calculated from the Lineweaver-Burk plot for the reciprocal of the reaction velocity $(1 / \mathrm{v})$ and substrate concentration (1/[S]) to be $1.1 \mathrm{mM}$ xanthine (Fig. 3b).

\section{Effect of divalent cations}

The purified buffalo liver xanthine oxidase was preincubated with $1 \mathrm{mM}$ and $2 \mathrm{mM}$ of each cation at $37^{\circ} \mathrm{C}$ and the activity was assayed. The data presented in Table (2) show the activity of BLXO in the presence of various cations. A control test without any cation was taken as $100 \%$ relative activity. $\mathrm{FeCl}_{2}$ activated the $\mathrm{BLXO}$ enzyme while $\mathrm{CuCl}_{2}, \mathrm{MnCl}_{2}$ and $\mathrm{ZnCl}_{2}$ were 
found to be potent inhibitors of buffalo liver xanthine oxidase BLXO activity.

Table. 2: Effect of divalent cations on the buffalo liver xanthine oxidase BLXO:

\begin{tabular}{ccc}
\hline \multirow{2}{*}{ Reagent } & Final Concentration (mM) & $\begin{array}{c}\text { BLXO Residual activity } \\
(\%)\end{array}$ \\
\hline Control & ---- & 100.0 \\
\hline \multirow{2}{*}{$\mathrm{CoCl}_{2}$} & 1.0 & 88.2 \\
& 2.0 & 85.1 \\
\multirow{2}{*}{$\mathrm{MnCl}_{2}$} & 1.0 & 48.8 \\
& 2.0 & 41.8 \\
\multirow{2}{*}{$\mathrm{FeCl}_{2}$} & 1.0 & 121.6 \\
& 2.0 & 138.4 \\
\multirow{2}{*}{$\mathrm{ZnCl}_{2}$} & 1.0 & 22.8 \\
& 2.0 & 16.6 \\
\multirow{2}{*}{$\mathrm{CuCl}_{2}$} & 1.0 & 31.3 \\
& 2.0 & 30.0 \\
\multirow{2}{*}{$\mathrm{NiCl}_{2}$} & 1.0 & 77.3 \\
& 2.0 & 101.5 \\
\multirow{2}{*}{$\mathrm{MgCl}_{2}$} & 1.0 & 78.8 \\
& 2.0 & 66.2 \\
\multirow{2}{*}{$\mathrm{CaCl}_{2}$} & 1.0 & 92.1 \\
\multirow{2}{*}{$\mathrm{These}_{\text {experiments }}$} & 2.0 & 66.2 \\
\hline
\end{tabular}

\section{Effect of various inhibitors}

The purified buffalo liver xanthine oxidase was preincubated with each inhibitor for $5 \mathrm{~min}$ at $37^{\circ} \mathrm{C}$ and the inhibition \% was calculated as a ratio of a control without inhibitor. Allopurinol is the strongest inhibitor of BLXO enzyme (Table 3).

Table. 3: Effect of inhibitors on the purified buffalo liver xanthine oxidase BLXO:

\begin{tabular}{|c|c|c|}
\hline Reagent & $\begin{array}{c}\text { Final } \\
\text { Concentration } \\
(\mathrm{mM})\end{array}$ & $\begin{array}{c}\text { BLXO } \\
\text { Inhibition } \\
(\%)\end{array}$ \\
\hline Control & ----- & 0.0 \\
\hline \multirow{2}{*}{ Allopurinol } & $1 \mathrm{mM}$ & 98.8 \\
\hline & $2 \mathrm{mM}$ & 100.0 \\
\hline \multirow{2}{*}{ Ethylenediamine tetraacetic acid (EDTA) } & $2 \mathrm{mM}$ & 4.5 \\
\hline & $5 \mathrm{mM}$ & 17.9 \\
\hline \multirow{2}{*}{ DL-Dithiothreitol (DTT) } & $2 \mathrm{mM}$ & 1.4 \\
\hline & $5 \mathrm{mM}$ & 3.5 \\
\hline \multirow{2}{*}{ Iodoacetamide } & $2 \mathrm{mM}$ & 12.2 \\
\hline & $5 \mathrm{mM}$ & 37.6 \\
\hline \multirow{2}{*}{ Hydrogen peroxide $\left(\mathrm{H}_{2} \mathrm{O}_{2}\right)$} & $2 \mathrm{mM}$ & 37.3 \\
\hline & $5 \mathrm{mM}$ & 55.8 \\
\hline \multirow{2}{*}{$\beta$-Mercaptoethanol } & $2 \mathrm{mM}$ & 2.2 \\
\hline & $5 \mathrm{mM}$ & 8.5 \\
\hline \multirow{2}{*}{ 1,10 Phenanthroline } & $2 \mathrm{mM}$ & 0.0 \\
\hline & $5 \mathrm{mM}$ & 2.5 \\
\hline \multirow{2}{*}{ Phenylmethylsulfonyl-fluoride (PMSF) } & $2 \mathrm{mM}$ & 1.2 \\
\hline & $5 \mathrm{mM}$ & 10.4 \\
\hline \multirow{2}{*}{ Potassium cyanide $(\mathrm{KCN})$} & $2 \mathrm{mM}$ & 1.5 \\
\hline & $5 \mathrm{mM}$ & 4.8 \\
\hline \multirow{2}{*}{ Potassium dichromate $\left(\mathrm{K}_{2} \mathrm{Cr}_{2} \mathrm{O}_{7}\right)$} & $2 \mathrm{mM}$ & 44.5 \\
\hline & $5 \mathrm{mM}$ & 78.4 \\
\hline \multirow[b]{2}{*}{ Sodium azide $\left(\mathrm{NaN}_{3}\right)$} & $2 \mathrm{mM}$ & 2.8 \\
\hline & $5 \mathrm{mM}$ & 20.9 \\
\hline \multirow{2}{*}{ Sodium dodecyl sulfate (SDS) } & $2 \mathrm{mM}$ & 69.9 \\
\hline & $5 \mathrm{mM}$ & 92.5 \\
\hline
\end{tabular}

* These values represent $\%$ of the control and the means of triplicate experiments

\section{Kinetics of BLXO inhibition by Allopurinol}

Allopurinol inhibited BLXO enzyme activity vigorously. A titration curve of allopurinol concentrations on the purified BLXO activity (Fig. 4a) indicated that 50\% inhibition $\left(\mathrm{I}_{50}\right)=0.05$ $\mathrm{mM}$ allopurinol. The maximum inhibition of the enzyme $(98.8 \%)$ was achieved by $1 \mathrm{mM}$ allopurinol. A linear relationship was observed by constructing the Hill plot for the inhibition of BLXO by allopurinol. The slope of the Hill plot is 0.8 (Fig. 4b), and allopurinol inhibited the BLXO activity competitively (Fig. 4c). The Ki value of the BLXO inhibition by allopurinol is determined to be $0.025 \mathrm{mM}$ (Fig. 4d).

\section{DISCUSSION}

Xanthine oxidase is a commercially important enzyme with a wide area of applications (Ozer et al., 1999). This study aims at purification of XO from buffalo liver to be used in preparation of SOD diagnostic kit. In this study, buffalo liver XO was purified by acetone fractionation, anion-exchange and gel filtration columns. Various purification procedures of $\mathrm{XO}$ were reported like that of mouse skeletal muscle; purified by ammonium sulfate fractionation, anion-exchange and affinity chromatographies (Lalanne and Willemot, 1975). XO from rat liver was purified by heat denaturation, ammonium sulphate precipitation, and chromatography on hydroxylapatite and QSepharose Fast Flow columns (Maia and Mira, 2002). Also, rat liver XO was purified by heat denaturation, ammonium sulphate precipitation and Chromatography on benzamidine-Sepharose column (McManaman et al., 1996). The chromatography of buffalo liver XO (BLXO) on DEAE-cellulose column revealed the presence of one $\mathrm{XO}$ activity peak eluted with $0.05 \mathrm{M} \mathrm{NaCl}$ (Fig. 1a). BLXO was purified from Sephacryl S-300 column (Fig. 1b) with a specific activity of 7.2 units / $\mathrm{mg}$ protein, 31.3 folds purification over the crude extract and $33.8 \%$ yield (Table 1). XO was purified from mouse liver 302-fold with 3.6\% yield (Carpani et al., 1990), from rabbit liver 330-fold with $16 \%$ yield (Catignani et al., 1975) and from rat liver 1200-fold with 20\% yield (Maia and Mira, 2002).

The purity of BLXO was investigated by analysis on $7 \%$ native-PAGE. BLXO turned out the presence of a major protein band which coincided with the enzyme activity band confirming that the single protein band is the enzyme band (Fig. 2a). The gel filtration chromatography calculated BLXO molecular weight to be $200 \mathrm{kDa}$ (Fig. 1b). The subunit molecular weight of BLXO isoenzyme was determined by SDS-PAGE to be $67 \mathrm{kDa}$ (Fig. 2b). In comparison with the native molecular weight, it was found that BLXO is homotrimer protein composed of three subunits. Many $\mathrm{XO}$ were reported to have a dimeric structure such as; human liver XO (Krenitsky et al., 1986), mouse liver XO (Carpani et al., 1990) and rat liver XO (Maia and Mira, 2002). The isoelectric point ( $p \mathrm{I})$ value is estimated for the purified BLXO isoenzyme from buffalo liver at $\mathrm{pH} 6.0-6.2$ (Fig. 2c). Various isoelectric points $(p \mathrm{I})$ values were reported as $\mathrm{XO}$ from mouse liver with $p \mathrm{I}$ value of 6.7 (Carpani et al., 1990) and XO from rat liver with $p$ I values of 6.13, 
6.23 and 6.07 (McManaman et al., 1996). The purified BLXO displayed its pH optima at 7.6 (Fig. 3a). Similarly, rabbit liver XO optimum pH was pH 8.1 (Catignani et al., 1975). BLXO enzyme has a $\mathrm{Km}$ value of $1.1 \mathrm{mM}$ xanthine (Fig. 3b) indicating the high affinity of BLXO toward xanthine. Mouse liver XO had $\mathrm{Km}$ value of $3.4 \mu \mathrm{M}$ xanthine (Carpani et al., 1990), of rabbit liver XO was $22 \mu \mathrm{M}$ (Catignani et al., 1975) and of rat liver XO was $53 \mu \mathrm{M}$ (McManaman et al., 1996). $\mathrm{FeCl}_{2}$ increased the activity of BLXO while $\mathrm{CuCl}_{2}, \mathrm{MnCl}_{2}$ and $\mathrm{ZnCl}_{2}$ inhibited the activity of it (Table 2). This was similar to that of cow milk xanthine oxidase which was inhibited by $\mathrm{Cu}^{+2}, \mathrm{Hg}^{+2}$ and $\mathrm{Ag}^{+}$ions (Mondal et al., 2000). Iodoacetamide inhibited the purified BLXO isoenzyme activity which indicates that the active site of this enzyme has methionine, cysteine and histidine residues that have important effects on the structure and activity of the enzyme. The inhibition of the purified BLXO isoenzyme by the metal chelator EDTA indicates that BLXO isoenzyme is metalloenzyme. BLXO activity was inhibited with $\mathrm{K}_{2} \mathrm{Cr}_{2} \mathrm{O}_{7}$ which may be due to strong oxidizing power of
$\mathrm{K}_{2} \mathrm{Cr}_{2} \mathrm{O}_{7}$ that may cause oxidation of metal prosthetic groups in enzyme that important to enzyme activity (Table 3). Allopurinol was found to be the most potent inhibitor of the purified BLXO (Table 3). $0.06 \mathrm{mM}$ allopurinol inhibited the purified BLXO 50\% and the maximum inhibition of the enzyme was achieved by $1 \mathrm{mM}$ (Fig. 4a). The slope of the Hill plot was found to be 0.8 (Fig. 4b) indicating the existence of one binding site for allopurinol on the purified BLXO. Allopurinol inhibited BLXO enzyme activity competitively (Fig. 4c) since the presence of allopurinol increased the $\mathrm{Km}$ value and did not alter the Vmax value. The $\mathrm{Ki}$ value of the BLXO inhibition by allopurinol is determined to be $0.025 \mathrm{mM}$ directly from the intercept of the $X$ axis of the plot (Fig. 4d). In conclusions, the present study reported buffalo liver xanthine oxidase (BLXO) and introduced a simple, convenient and reproducible method for the purification of well characterized xanthine oxidase from buffalo liver as a locally available source. Production of this enzyme on large scale will make it suitable for preparation of SOD diagnostic kit.
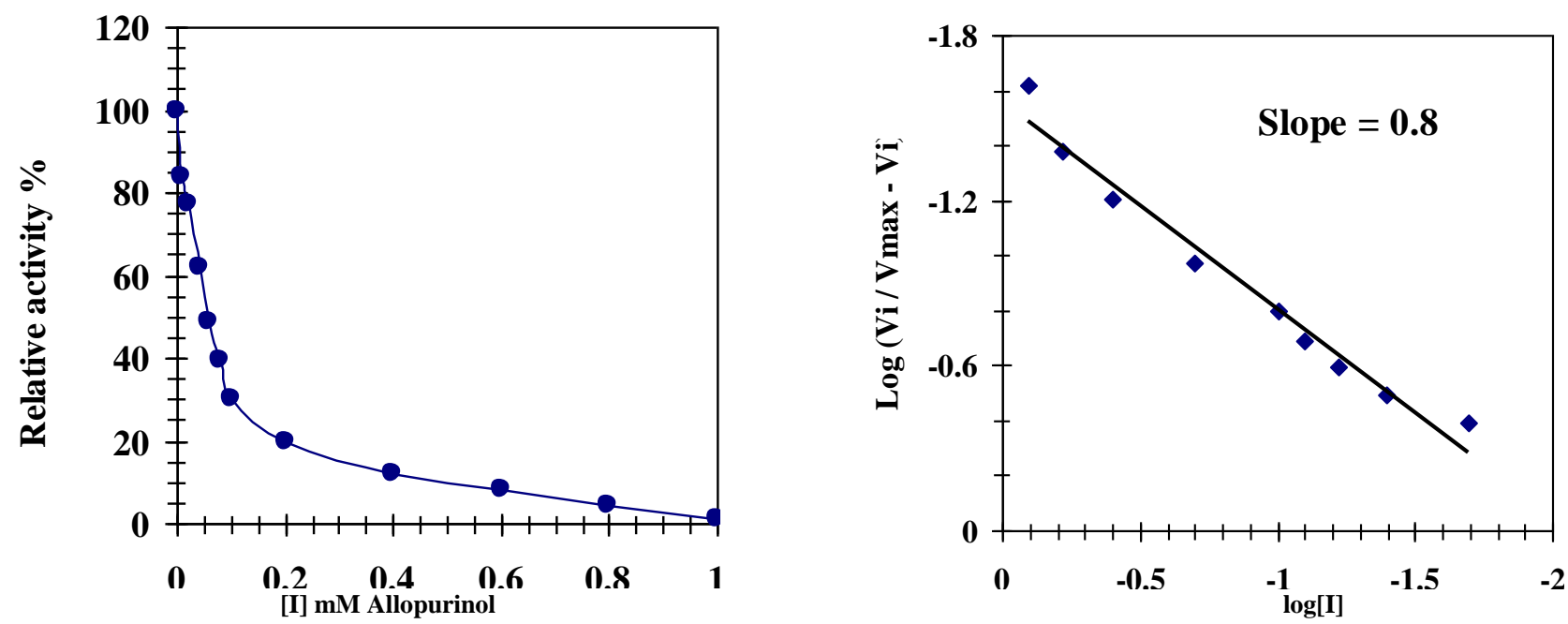

Fig. 4: (a) Inhibition of BLXO by varying concentrations of allopurinol. (b) Hill plot for inhibition of BLXO by allopurinol.
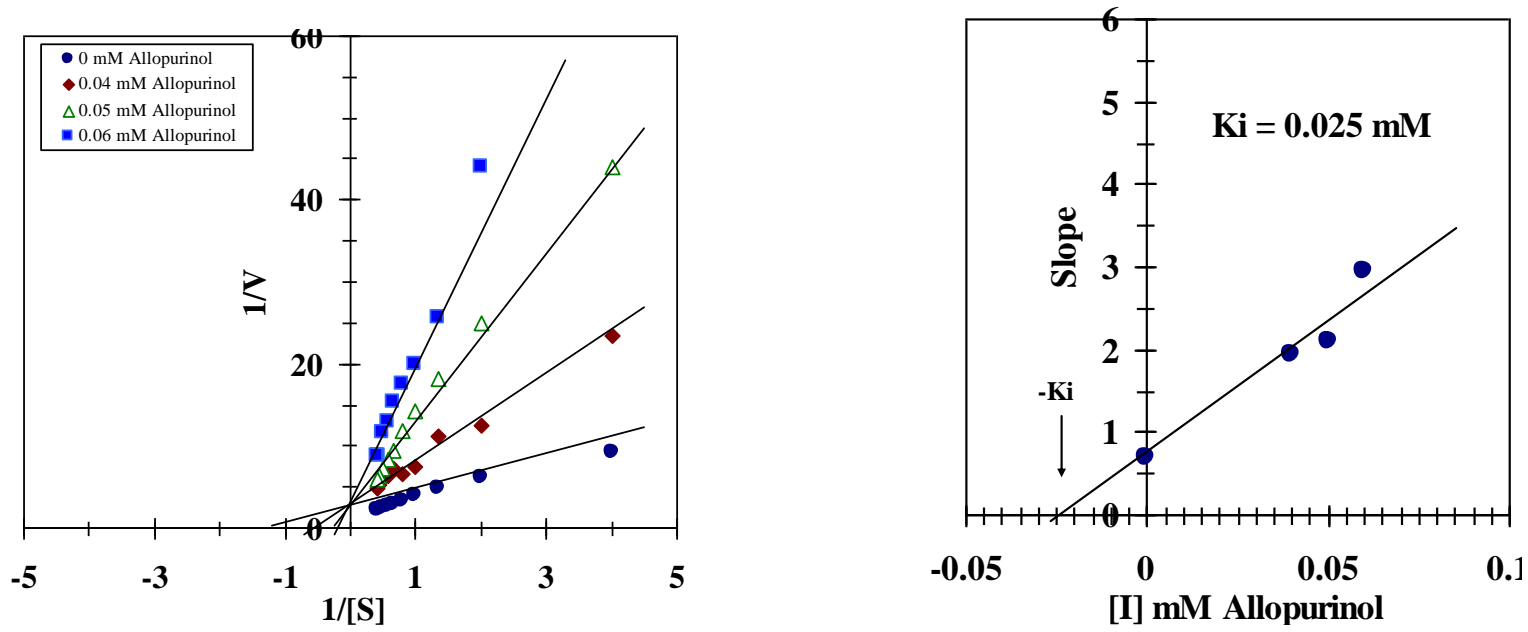

Fig. 4: (c) Lineweaver-Burk plots showing the type of inhibition of BLXO by allopurinol. (d) Determination of the inhibition constant (Ki) value for the inhibition of the BLXO by allopurinol. 


\section{ACKNOWLEDGEMENTS}

The authors would gratefully acknowledge financial support provided by the National Research Centre of Egypt under the contract No. 10030002.

\section{REFERENCES}

Abadeh, S., Killacky, J., Benboubetra, M., and Harrison, R.. Purification and partial characterization of xanthine oxidase from human milk. Biochem. Biophys. Act., 1992; 1117: 25-32.

Agarwal A., and Banerjee, U.C.. Screening of Xanthine Oxidase Producing Microorganisms Using Nitroblue Tetrazolium Based Colorimetric Assay Method. The Open Biotechnology Journal, 2009; 3: 46-49.

Belattar, N. Adsorption property and affinity chromatography of polystyrene derivative sorbent towards cow's milk xanthine oxidase. Mat. Sci. Engin. C., 2009; 29: 1540-1544.

Berry, C.E., and Hare, J.M. Xanthine oxidoreductase and cardiovascular disease: molecular mechanisms and pathophysiological implications. J. Physiol., 2004; 555(3): 589-606.

Bradford, M.M. A rapid and sensitive method for the quantitation of microgram quantities of protein utilizing the principle of protein-dye binding. Anal. Biochem., 1976; 72: 248-254.

Carpani, G., Racchi, M., Ghezzi, P., Terao, M., and Garattini, E. Purification and characterization of mouse liver xanthine oxidase. Arch. Biochem Biophys, 1990; 279: 237-241.

Catignani, G.L., Chytil, F., and Darby, W.J. Purification and characterization of xanthine oxidase from livers of vitamin e deficient rabbits. Arch. Biochem Biophys, 1975; 377: 34-41.

Groot, H.D., and Noll, T. Enzymic determination of inorganic phosphates, organic phosphates and phosphate-liberating enzymes by use of nucleoside phosphorylase-xanthine oxidase (dehydrogenase)-coupled reactions.Biochem. J., 1985; 230: 255-260.

Heinz, F., Pilz, R., Reckel, S., Kalden, J.R., and Haeckel, R. A new spectrophotometric method for the determination of 5'-nucleotidase. J. Clin. Chem. Clin. Biochem., 1980; 18(11): 781-788.

Higgins, P., Ferguson, L.D., and Walters, M.R. Xanthine oxidase inhibition for the treatment of stroke disease: a novel therapeutic approach. Expert Rev. Cardiovasc. Ther., 2011; 9(4): 399-401.

Krenitsky, T.A., Spector, T., and Hall, W.W. Xanthine oxidase from human liver: purification and characterization. Arch. Biochem Biophys., 1986; 247: 108-119.

Kuwabara, Y., Nishino, T., Okamoto, K., Matsumura, T., Eger, B.T., Pai, E.F. and Nishino, T. Unique amino acids cluster for switching from the dehydrogenase to oxidase form of xanthine oxidoreductase. Proc. Natl. Acad. Sci., 2003; 100(14): 8170-8175.

Laemmli, U.K. Cleavage of structural proteins during the assembly of the head of Bacteriophage T4. Nature, 1970; 227: 680-685.

Lalanne, M., and Willemot, J. Xanthine oxidase from mouse skeletal muscle: purification and kinetic studies. Inf. J. Biochem., 1975; 6: 479-484.

Maia, L., and Mira, L. Xanthine oxidase and aldehyde oxidase: A simple procedure for the simultaneous purification from rat liver. Arch. Biochem Biophys., 2002; 400: 48-53.

Martin, H.M., Hancock, J.T., Salisbury, V., and Harrison, R. Role of xanthine oxidoreductase as an antimicrobial agent. Infect. Immun., 2004; 72(9): 4933-4939.

McManaman, J.L., Shellman, V., Wright, R.M., and Repine, J.E. Purification of rat liver xanthine oxidase and xanthine dehydrogenase by affinity chromatography on benzamidine-sepharose. Arch. Biochem Biophys., 1996; 332: 135-141.
Mondal, M.S., Sau; A.K., and Mitra, S. Mechanism of the inhibition of milk xanthine oxidase activity by metal ions: a transient kinetic study. Biochim. Biophys. Act., 2000; 1480: 302-310.

Moriwaki, Y., Yamamoto, T., Suda, M., Nasako, Y., Takahashi, S., Agbedana, O.E., Hada, T., and Higashino, K. Purification and immunohistochemical tissue localization of human xanthine oxidase. Biochem. Biophys. Act., 1993; 1164: 327-330.

Nguyen, M.T.T., Awale, S., Tezuka, Y., Tran, Q.L., and Kadota, S. Xanthine oxidase inhibitors from the heartwood of Vietnamese Caesalpinia sappan. Chem. Pharm. Bull., 2005; 53(8): 984-988.

Nishino, T., Nishino, T., and Tsushima, K. Purification of highly active milk xanthine oxidase by affinity chromatography on sepharose 4B/folate gel. FEBS Lett., 1981; 131: 369-372.

O'Farrell, P.H. High resolution two-dimensional electrophoresis of proteins. J. Biol. Chem., 1975; 250: 4007-4021.

Oida, S.; Sone, M., and Sasaki, S. Purification of swine alkaline phosphatase by immunoaffinity chromatography. Anal. Biochem., 1984; 140: $117-120$.

Ozer, N., Muftuoglu, M., and Ogus, I.H. A simple and sensitive method for activity staining of xanthine oxidase. J. Biochem. Biophys. Methods., 1998; 36: 95-100.

Ozer, N., Muftuoglu, M., Ataman, D., Ercan, A., and Ogus, I.H. Simple, high-yield purification of xanthine oxidase from bovine milk. J. Biochem. Biophys. Methods., 1999; 39: 153-159.

Smith, I. 1969. Acrylamide gel disc electrophoresis. In: Smith, I., (Eds.), Electrophoretic techniques, Academic press, New York, pp. 365-515.

Spitsberg, V.L., and Gorewit, R.C. Solubilization and purification of xanthine oxidase from bovine milk fat globule membrane. Prot. Expres. Purif., 1998; 13: 229-234.

Ubuka, T., Masuoka, N., Yoshida, S., Ishino, K. Determination of isoelectric point value of 3-Mercaptopyruvate sulfurtransferase by isoelectric focusing using ribonuclease A-glutathione mixed disulfides as standards. Anal. Biochem, 1987; 167: 284-289.

Vorbach, C., Roger, H. and Capecchi, M.R. Xanthine oxidoreductase is central to the evolution and function of the innate immune system. Trends Immunol, 2003; 24(9): 512-517.

Waud, W.R., Brady, F.O., Wiley, R.D., and Rajagopalan, K.V. A new purification procedure for bovine milk xanthine oxidase: effect of proteolysis on the subunit structure. Arch. Biochem. Biophys, 1975; 169: 695-701.

Weber, K, Osborn, M. The reliability of molecular weight determinations by dodecyl sulfate-polyacrylamide gel electrophoresis. J Biol Chem, 1969; 244: 4406-4412.

Xin, Y., Yang, H., Xia, X., Zhang, L., Zhang, Y., Cheng, C., and Wang, W. Expression, purification and partial characterization of a xanthine oxidase (XOD) in Arthrobacter sp. Proc. Biochem, 2012; 47: $1539-1544$.

Zhang, Y., Xin, Y., Yang, H., Zhang, L., Xia, X., Tong, Y., Chen, Y., Ma, L., and Wang, W. Novel affinity purification of xanthine oxidase from Arthrobacter M3. J. Chromatog. B, 2012; 906: 19-24.

\section{How to cite this article:}

Ibrahim MA, Masoud HMM, Darwish DA, Esa SS, Zaahkouk SAM. Purification and characterization of xanthine oxidase from liver of the water buffalo Bubalus bubalis. J App Pharm Sci, 2015; 5 (11): 063-068 